\title{
INTEGRAÇÃO DE PARÂMETROS FÍSICOS DO MAGMA E COMPOSIÇÃO QUIIMICA DOS MINERAIS NA PETROGÊNESE DO GRANITO ITAPEMA, SC*
}

\author{
CRISTIANE BUTORI RIVERA ${ }^{1}$, MARIA DE FÁTIMA BITENCOURT ${ }^{2}$ \& \\ LAURO VALENTIMSTOLL NARDI ${ }^{2}$
}

\begin{abstract}
INTEGRATION OF PHYSICAL PARAMETERS AND MINERALOGICAL CHEMICAL COMPOSITION IN THE PETROGENESIS OF THE ITAPEMA GRANITE. SC The Itapema Granite, located in the Catarinense Shield, southern Brazil, is a late-orogenic intrusion in the Paleoproterozoic Camboriu Complex gneisses, and shows U-Pb age of $2011 \pm 14 \mathrm{Ma}$. It is composed of hornblende-biotite granodiorites and biotite monzogranites, which are distributed in two main facies: a fine to medium-grained equigranular facies and a heterogranular one. The Itapema Granite shows a well-developed magmatic foliation, abundant xenoliths of metamorphic rocks, and autoliths formed mainly by cumulatic plagioclase and amphibole. Lithostatic pressure during magmatic crystallization was estimated based on total-Al content in horblende and on the presence of magmatic epidote, at 4 to $4.5 \mathrm{kbar}$. Liquidus temperature, based on zirconium solubility curves, is estimated at about $800^{\circ} \mathrm{C}$, and solidus temperature at about $700^{\circ} \mathrm{C}$, which is indicated by the hornblende-plagioclase geothemometer. The generation of chessboard pattern in quartz suggests solidus temperatures over 665 to $6900^{\circ} \mathrm{C}$ for pressures of 3.84 and $4.7 \mathrm{kbar}$, respectively. The natural viscosity of magmatic liquids varied from $10^{4}$ to $10^{5} \mathrm{~Pa}$.s. Three rheological domains are presumed during magma crystallization: a solid domain, a mush domain, and a liquid one, which produced the autholiths and xenoliths, the heterogranular and the equigranular facies, respectively. The lithological variation of Itapema Granite is controlled mainly by mineral segregation and frąctionation promoted by magmatic flow.
\end{abstract}

Keywords: granitoid petrogenesis, mineral chemistry, rheology of granitic systems, magmatic flow.

\begin{abstract}
Resumo O Granito Itapema, localizado no Escudo Catarinense, é intrusivo em gnaisses paleoproterozóicos do Complexo Camboriú, possui idade U-Pb de $202 \mathrm{I} \pm 14 \mathrm{Ma}$, e seu posicionamento é tardio em relação à tectônica tangencial da região. A intrusão compreende hornblenda-biotita granodioritos a biotita monzogranitos, onde foram identificadas duas fácies principais: fácies heterogranular e fácies equigranular fina a média. O granito possui uma foliação magmática bem desenvolvida e abundantes xenólitos e autólitos. Os autólitos são formados predominantemente por anfibólio e plagioclásio de caráter cumulático. A pressão litostática durante a cristalização magmática foi estimada em 4-4,5 kbar, com base no teor de Al' na hornblenda e na presença de epidoto magmático. A temperatura próxima da curva liquiidıs, determinada com base na solubilidade do zircônio, é de $800^{\circ} \mathrm{C}$, e a temperatura próxima da curva solidlus, determinada pelo par hornblenda-plagioclásio, é de $700^{\circ} \mathrm{C}$. A temperatura de geração de subgrãos em padrão tabuleiro de xadrez no quartzo foi estimada $\mathrm{em} 665^{\circ} \mathrm{e} 690^{\circ} \mathrm{C}$, para pressões de $3,84 \mathrm{e} 4,7 \mathrm{kbar}$, respectivamente. A viscosidade natural dos líquidos magmáticos foi estimada em $10^{4}$ a $10^{5} \mathrm{~Pa}$.s. Três domínios reológicos são supostos durante a cristalização magmática: domínio sólido, domínio pasta e domínio líquido. Estes domínios se refletem nos principais tipos litológicos reconhecidos no Granito Itapema, que são: autólitos e xenólitos, fácies heterogranular e fácies equigranular fina a média. A variação litológica do Granito Itapema é controlada principalmente por segregação e fracionamento mineral causado pelo fluxo magmático.
\end{abstract}

Palavras-chave: petrogênese de granitóides, química mineral, reologia de sistemas graníticos, fluxo magmático.

INTRODUÇÃO OGranito Itapemaé uma intrusão recentemente mapeada na região nordeste do Escudo Catarinense (UFRGS 2000), e caracterizada, do ponto de vista estrutural e geoquímico, por Bitencourt \& Nardi (2004). Suas características estruturais e relações com as rochas encaixantes sugerem que representa um episódio magmático desvinculado do magmatismo granítico sintectônico às zonas de cisalhamento transcorrentes neoproterozóicas do sul do Brasil, o que é confirmado por dados geocronológicos apresentados por Hartmann et al. (2003).

A discussão de um modelo evolutivo coerente para explicar sua variação composicional, textural e estrutural constitui o principal objetivo deste trabalho. Para tanto, são utilizados dados préexistentes, acrescidos de novas observações de campo e dados de petrografia e química mineral, integrados para a construção de um modelo de evolução petrogenética.

GEOLOGIA REGIONAL A regiãonordeste do setor meridional da Província Mantiqueira (Fig.1a), que compreende o Escudo Catarinense, pode ser compartimentada com referência às duas grandes estruturas transcorrentes da sua região central: a Zona de Cisalhamento Itajaí (ZCI) e a Zona de Cisalhamento Major
Gercino(ZCMG) (Fig.lb). Ambas fazem parte do Cinturão de Cisalhamento Sul-brasileiro (Bitencourt \& Nardi 2000).

A ZCI (Silva et al. 2000) tem direção NE, 10 a $15 \mathrm{~km}$ de largura e movimento destral. A norte desta zona situam-se o Complexo Granulítico de Santa Catarina (CGSC) e as sequiências vulcanosedimentares da Bacia do Itajái. No CGSC (Hartmann et al. 1979), dados U-Pb em zircões obtidos por Harara (2001) indicam dois eventos de metamorfismo de fácies granulito, com idades de 2,2 Ga e 2,06 Ga. A ZCMG (Bitencourt et al.1989) tem direção NE, aproximadamente $20 \mathrm{~km}$ de largura e movimento destral. A sul desta zona ocorre uma extensa área de granitóides neoproterozóicos (Fig. 1b), representativos de diversos pulsos de magmatismo granítico e máfico sincrônicos, controlados por zonas de cisalhamento de direção NE a NNE.

O Complexo Metamórfico Brusque - CMB (Philipp et al. 2003) é composto por sequiências supracrustais cujo ambiente de deposição pode estar relacionado a uma margem continental passiva (Basei 1985) ou a um rift intracontinental (Silva 1991, Philipp et al. 2003). Para Basei (1990), o clímax metamórfico do CMB ocorreu há $706 \mathrm{Ma}$, valor obtido pelo método Rb-Sr (rocha total) em biotita gnaisse.

\footnotetext{
* - As tabelas mencionadas no artigo sob os $n^{\omega *} 2,3$ e 5 podem ser obtidas mediante solicitação por e-mail ao Autor Correspondente.

1 - Universidade Federal do Rio Grande do Sul, Instituto de Geociências, Programa de Pós-graduação em Geociências

2 - Universidade Federal do Rio Grande do Sul, Instituto de Geociências

2 - Autor Correspondente: Caixa Postal 15.001, CEP 91501-970, Porto Alegre, RS, e-mail: fatimab@ufrgs.br
} 
O Complexo Camboriú (CC) é uma associação de gnaisses, migmatitos e granitos, com foliação suborizontal. Este complexo ocorre no Escudo Catarinense em quatro áreas (Fig. Ib), sob diferentes designações locais. Os dados U-Pb SHRIMP em zircões, obtidos por Silva et al. (2000) indicam idade magmática de $c a$. 2,20 Ga, com metamorfismo principal há ca. 2,0 Ga.

A área de estudo (Fig l) situa-se na região compreendida entre a ZCI e a ZCMG. Constitui uma zona de baixa deformação transcorrente e consta nos mapas de pequena escala como uma região de predomínio do Complexo Camboriú. O mapeamento geológico 1:25000 efetuado por alunos e professores do Curso de Geologia da Universidade Federal do Rio Grande do Sul nas foIhas Camboriú e Itajaí (Projeto Camboriú - UFRGS 2000) permitiu desmembrar esta ocorrência em uma área gnáissica, para a qual se manteve a designação de Complexo Camboriú, e uma extensa área granítica que antecede suítes neoproterozóicas denominada Gra- nito Itapema (Fig. 2). As rochas do CMB ocorrem a norte e a sul desta faixa central, e vários corpos graníticos neoproterozóicos foram intrudidos no conjunto, com idade entre $638 \mathrm{Ma}$ (Basei et al. 2000) e $593 \mathrm{Ma}$ (Silva 1999). Segundo Bitencourt \& Nardi (2004), o quadro geológico da figura 2 sugere que esta região representa a porção de topo de volumosa massa granítica com diversos fragmentos das encaixantes, interpretados como roof-pendants.

O Complexo Camboriú, na área estudada, é uma associação de orto-e paragnaisses quartzo-feldspáticos e anfibolíticos, subordinadamente pelíticos e calcissilicatados. Sua estrutura principal é um bandamento regular e contínuo, dado pela alternância de bandas máficas e félsicas, da fácies anfibolito médio a superior acompanhado de migmatização e geração de leucogranitos. A geometria original suborizontal do bandamento é reconstituída apenas localizadamente (Philipp et al. 2001) devido à superposição de dobras isoclinais e cisalhamento, em condições de alta temperatu-

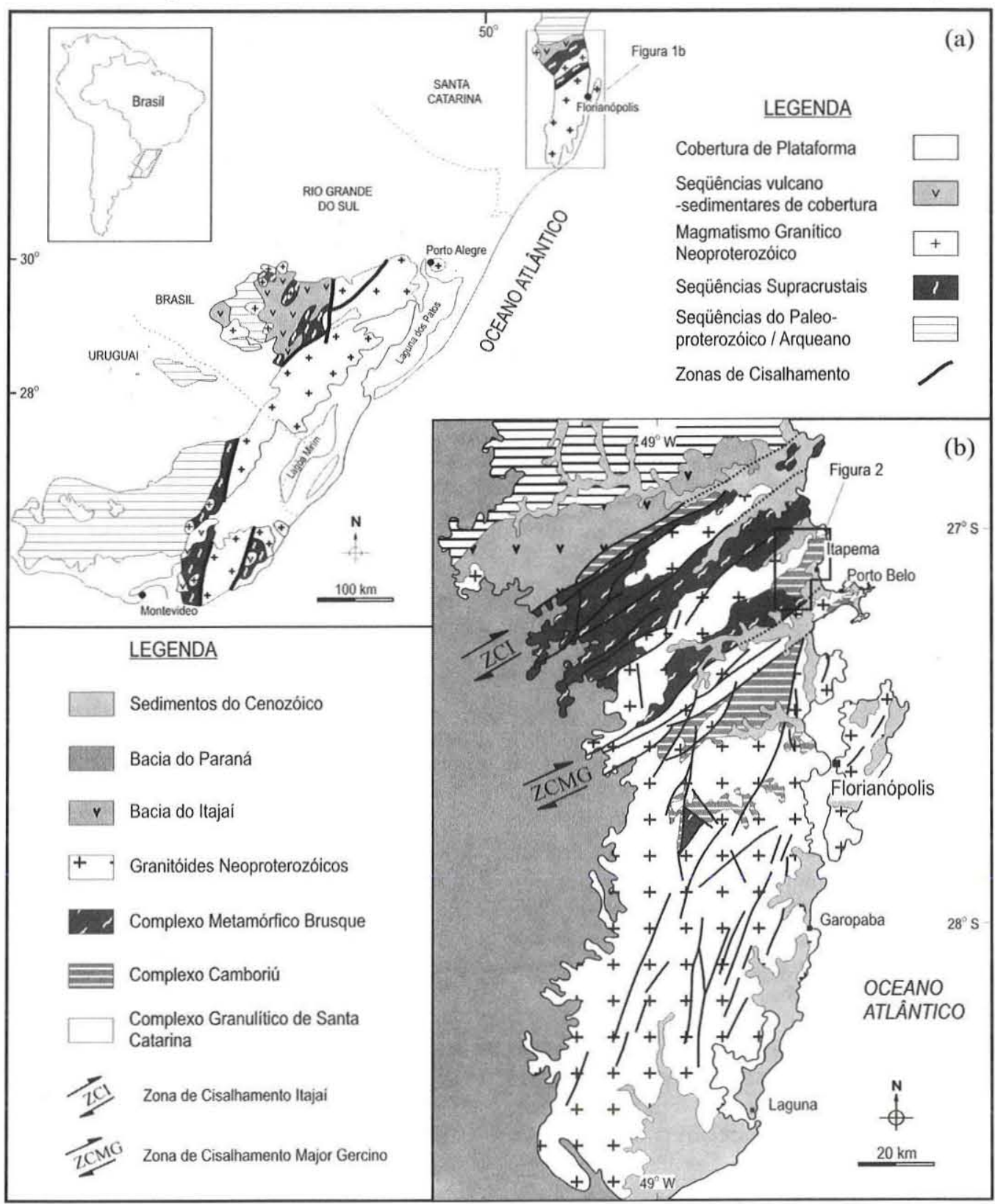

Figura 1- Contexto geológico e geotectônico regional (modificado de Bitencourt \& Nardi 2004): (a) compartimentação dos escudos Catarinense, Sul-rio-grandense e Uruguaio; (b) compartimentação geológica e principais traços tectônicos de parte do Escudo Catarinense. 
ra, seguidos por dobras abertas, em temperatura decrescente. As lineações mineral e de estiramento caem preferencialmente para $\mathrm{NE}$ a N, com baixo ângulo. Os dados U-Pb SHRIMP obtidos por Silva et al. (2000) indicam idades metamórficas (M1 e M2) de 2160 \pm 20 Ma e $1979 \pm 42$ Ma para anfibolitos do CC, com superposição de um evento hidrotermal em ca. $590 \mathrm{Ma}$.

$\mathrm{O} \mathrm{CMB}$ é constituído por sequências metassedimentares clásticas e químicas, com ocorrência subordinada de rochas metavulcânicas (Philipp et al. 2003); a xistosidade principal (S1// S2) mergulha com baixo a médio ângulo para SW ou NW (Fig. 2).

Na porção sul da área estudada (Fig. 2), uma pequena ocorrência de milonitos quartzo-feldspáticos foi individualizada por UFRGS (2000). Estas rochas são bandadas, com lineação de estiramento NW-SE contida numa foliação milonítica que mergulha a baixo âgulo para SE. As microestruturas indicam a superposição de deformação milonítica de fácies xistos verdes sobre uma trama da fácies anfibolito médio a superior, o que permite identificar apenas localizadamente a composição granítica de seu protólito.
Os metamorfitos do CMB situam-se estruturalmente acima e abaixo destes milonitos (Fig. 2), possuem paragênese metamórfica de fácies xistos verdes a anfibolito inferior, excetuando-se os efeitos de metamorfismo de contato. Os dados U-Pb em zircões obtidos por Hartmann et al. (2003) indicam idade magmática de 2.162 16 Ma, compatível com a do primeiro metamorfismo obtida por Silva et al. (2000) em anfibolitos. A idade deformacional destes milonitos permanece indeterminada.

Os dados de campo e microestruturais, em conjunto com os geocronológicos, permitem sugerir um evento de thrusting com direção NW-SE, responsável pelo contato entre o CMB e o CC, na forma de fatias tectônicas. Este evento foi assumido como tardio em relação ao bandamento principal do $\mathrm{CC}$ devido à deformação de baixa temperatura dos milonitos, não registrada no bandamento dos gnaisses. O sentido de thrusting é compatível com o movimento de topo-para-NW apontado por Basei (1985) nos metamorfitos do $\mathrm{CMB}$, com base na vergência de dobras regionais.

O Granito Itapema (GI) é intrusivo nos gnaisses do CC, e sua

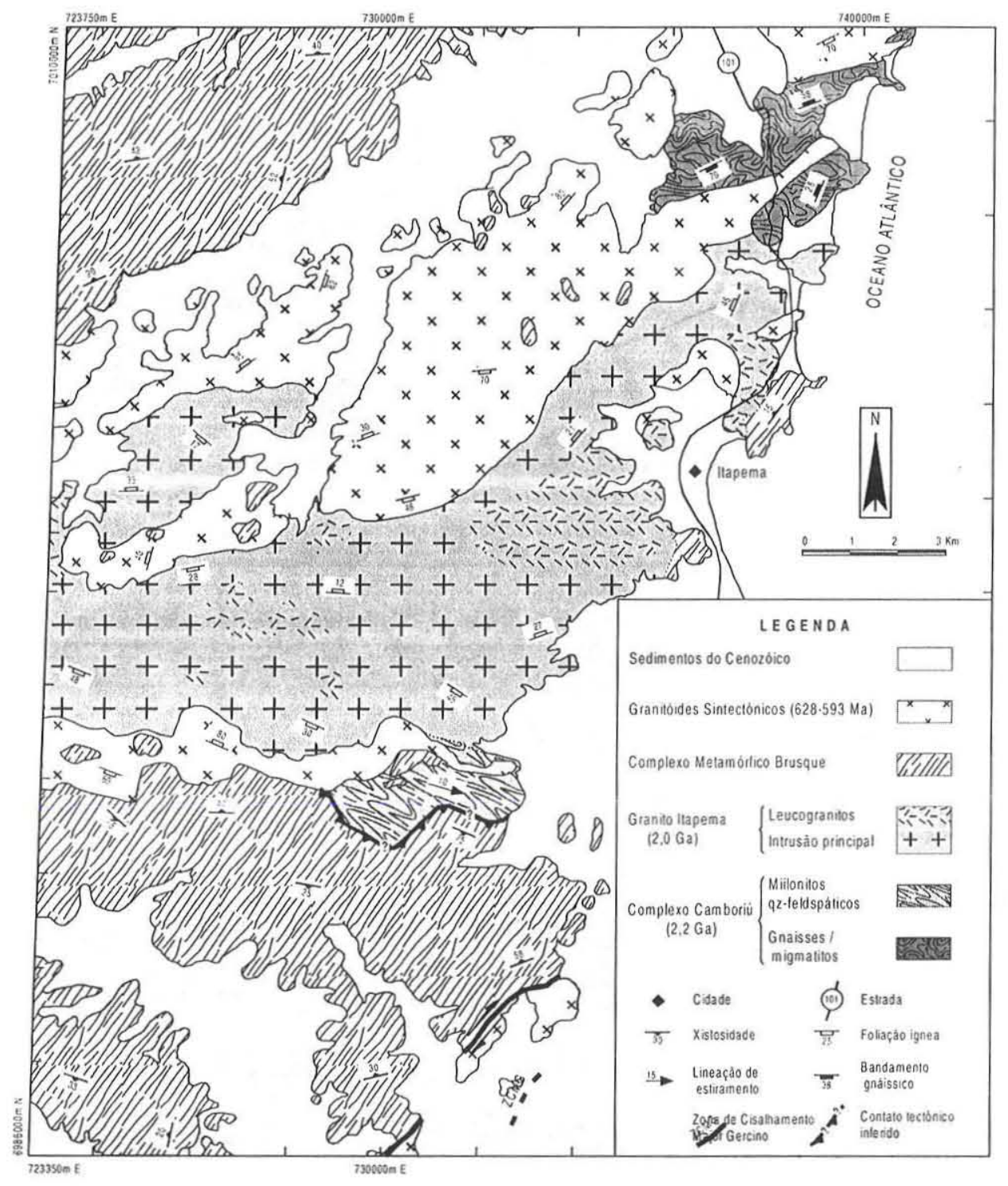

Figura 2 - Mapa geológico da região de Itapema, SC (modificado de UFRGS 2000). 
ocorrência provavelmente se estende para a folha contígua, mas seu limite oeste não é conhecido. Na região de Camboriú, os dados U-Pb SHRIMP em zircões de rochas interpretadas como ortognaisses (Silva et al. 2000), indicam idade magmática de 2006 $\pm 3 \mathrm{Ma}$, com superposição de um evento hidrotermal há ca.590 Ma. Segundo Bitencourt \& Nardi (2004), a localização e descrição apresentada por aqueles autores indica que a idade de cristalização magmática foi obtida nos termos bandados do Granito Itapema, próximo ao contato intrusivo com os gnaisses do Complexo Camboriú. Os dados U-Pb SHRIMP obtidos em amostra do centro da intrusão (Hartmann et al. 2003) confirmam a idade paleoproterozóica do GI, com o valor de $2021 \pm 14 \mathrm{Ma}$, dentro da margem de erro da idade obtida por Silva et al. (2000). Indicam também a presença de zircões herdados, com até ca. 2,9 Ga, bem como a superposição de um evento hidrotermal registrado nas bordas dos cristais de zircão, há ca. $590 \mathrm{Ma}$.

$\mathrm{O}$ granitóides neoproterozóicos são correlacionados à Suíte Intrusiva Valsungana - SIVG (Caldasso et al. 1995). São principalmente hornblenda-biotita monzogranitos porfiríticos de granulação grossa, e biotita sienogranitos de equigranulares finos, intrusivos nos primeiros. Os termos porfiríticos contêm xenólitos centimétricos a métricos de rochas dos complexos Brusque e Camboriú, e do Granito Itapema, desenvolvento margem de resfriamento contra o último. Nas rochas metamórficas, geram auréola de metamorfismo de contato da fácies hornblenda cornubianito.

GEOLOGIA E ESTRUTURA DO GRANITO ITAPEMA O Granito Itapema é uma intrusão com cerca de $100 \mathrm{~km}^{2}$ na área estudada, de orientação principal EW a NE-SW (Fig. 2). Seus contatos com os metamorfitos do CMB e com os gnaisses do CC são parcialmente obliterados pelos granitóides neoproterozóicos, e grande parte da sua borda sudeste é coberta por sedimentos cenozóicos.

A intrusão compreende hornblenda-biotita granodioritos a biotita monzogranitos de textura heterogranular média a fina, cujos acessórios típicos são alanita e titanita. O teor de minerais máficos é muito variável e ocorrem em aglomerados alongados, de tamanho variado e distribuição irregular. A característica marcante do granito é a abundância de enclaves (Fig. 3a), reunidos em dois grupos: (i) xenólitos das encainxantes, angulosos ou arredondados, de contatos retos ou irregulares e dimensões centimétricas a métricas e (ii) autólitos arredondados ou irregulares, contatos lobados, nítidos ou difusos, com progressiva desagregação e que se diferenciam pela textura equigranular média a grossa e ausência de bandamento metamórfico. Subordinadamente, o GI contem área significativa (Fig. 2) de leucogranitos equigranulares finos a heterogranulares e contatos nítidos ou gradacionais. Esses termos raramente contêm xenólitos ou autólitos e comumente contêm abundantes veios e bolsões irregulares aplítico-pegmatíticos.

A principal estrutura em toda a extensão dos granitóides é uma foliação de fluxo suborizontal (Fig. 3a), cuja morfologia varia com o grau de interação do magma com os enclaves. Em geral, a foliação é marcada pelo alinhamento de aglomerados máficos alongados, o que gera uma estrutura do tipo schlieren (Fig. 3c), por segregação de fases máficas e félsicas em bandas irregulares, descontínuas e contatos difusos. Subordinadamente, ocorre um bandamento de fluxo mais regular, ao longo do qual se alternam termos leucomonzograníticos finos e termos granodioríticos heterogra-nulares leucocráticos a mesocráticos (Fig. 3a e d). Em ambos os casos, é característica a ausência de deformação interna significativa dos constituintes. Localizadamente, ocorrem bolsões irregulares de aplitos e pegmatitos, com frequência alongados na direção do fluxo (Fig. 3b).

A foliação e o bandamento de fluxo são realçados por aglomerados máficos, na maior parte provenientes da desagregação de autólitos (Fig. 4a e b). É comum a ocorrência de autólitos máficos discóides, dispostos no plano da foliação. A maior regularidade e menor espaçamento entre bandas de composição e textura distintas associa-se principalmente às zonas ricas em xenólitos, o que carateriza fluxo mais intenso, com frequêencia canalizado entre os fragmentos. Nestas zonas, há uma relação espacial entre a abundância de aglomerados máficos e as zonas de baixa velocidade situadas nas extremidades de fragmentos sólidos (Fig. 5a).

Segundo Bitencourt \& Nardi (2004), o Granito Itapema é uma intrusão tabular, e sua porção norte, próxima ao contato com os gnaisses do Complexo Camboriú, é uma região onde o bandamento de fluxo está excepcionalmente bem desenvolvido, geralmente concordante com a estrutura suborizontal dos gnaisses. Entretanto, a natureza intrusiva do contato é dada por apófises, onde a foliação de fluxo é paralela aos contatos da intrusão e discordante do bandamento gnáissico da encaixante.

PETROGRAFIAEMICROESTRUTURAS Granitóides Por critérios petrográficos, as rochas da intrusão principal do Granito Itapema se agrupam em fácies heterogranular e fácies equigranular fina a média (Fig. 5a), com ampla predominância da primeira. O contato entre elas é geralmente difuso. Em ambas as fácies, ocorre uma foliação de forma, desenvolvida em maior ou menor grau, dada principalmente pelo alinhamento de agregados máficos alongados e raramente prismas de feldspatos. A composição modal de amostras representativas de cada fácies é dada na Tabela 1.

Os termos heterogranulares são hornblenda-biotita granodioritos a monzogranitos de textura hipidiomórfica média a fina (Fig. 5b). Os minerais máficos formam aglomerados de diâmetro milimétrico a centimétrico, cuja distribuição irregular acarreta variação mesoscópica e macroscópica do índice colorimétrico (M). Os termos equigranulares são biotita monzogranitos de textura hipidiomórfica fina a média (Fig. 5c), com amplo intervalo do grau de diferenciação dado pelas variáveis proporções de biotita e Kfeldspato. Nos termos menos diferenciados, raros cristais de hornblenda ocorrem no núcleo de agregados de biotita. Comparado ao dos granitóides heterogranulares, o teor de minerais máficos é menor, ainda que variável, mantendo-se a tendência a formar aglomerados de distribuição irregular. As fases minerais desta fácies tendem a um grau de euedria menor, principalmente nos termos mais diferenciados. Já os termos menos diferenciados, embora ainda tendendo à equigranularidade, contêm cristais esparsos de feldspatos de até $3,5 \mathrm{~mm}$.

O plagioclásio tem composição $\mathrm{An}_{20-32}$ nas amostras da fácies heterogranular e nos termos menos diferenciados da fácies equigranular fina, e $\mathrm{An}_{3-18}$ nos termos mais diferenciados desta fácies. É o mineral de maior variação de tamanho na fácies heterogranular; seus cristais são subédricos, têm zonação normal $\left(\mathrm{An}_{29-18}\right)$ e contêm inclusões de biotita, plagioclásio, zircão, epidoto, anfibólio, feldspato alcalino e apatita. Nos termos equigranulares finos, a zonação é pouco comum $\left(\mathrm{An}_{30-20}\right)$ e restrita a alguns cristais maiores, com o limite entre zonas às vezes marcado por inclusões globulares de quartzo. Os cristais contêm, ainda, poucas inclusões de biotita e plagioclásio $\left(\mathrm{An}_{16-24}\right)$.

Em geral, os cristais de plagioclásio têm maclas polissintéticas regulares e sua extinção ondulante é comum. Os cristais maiores, 

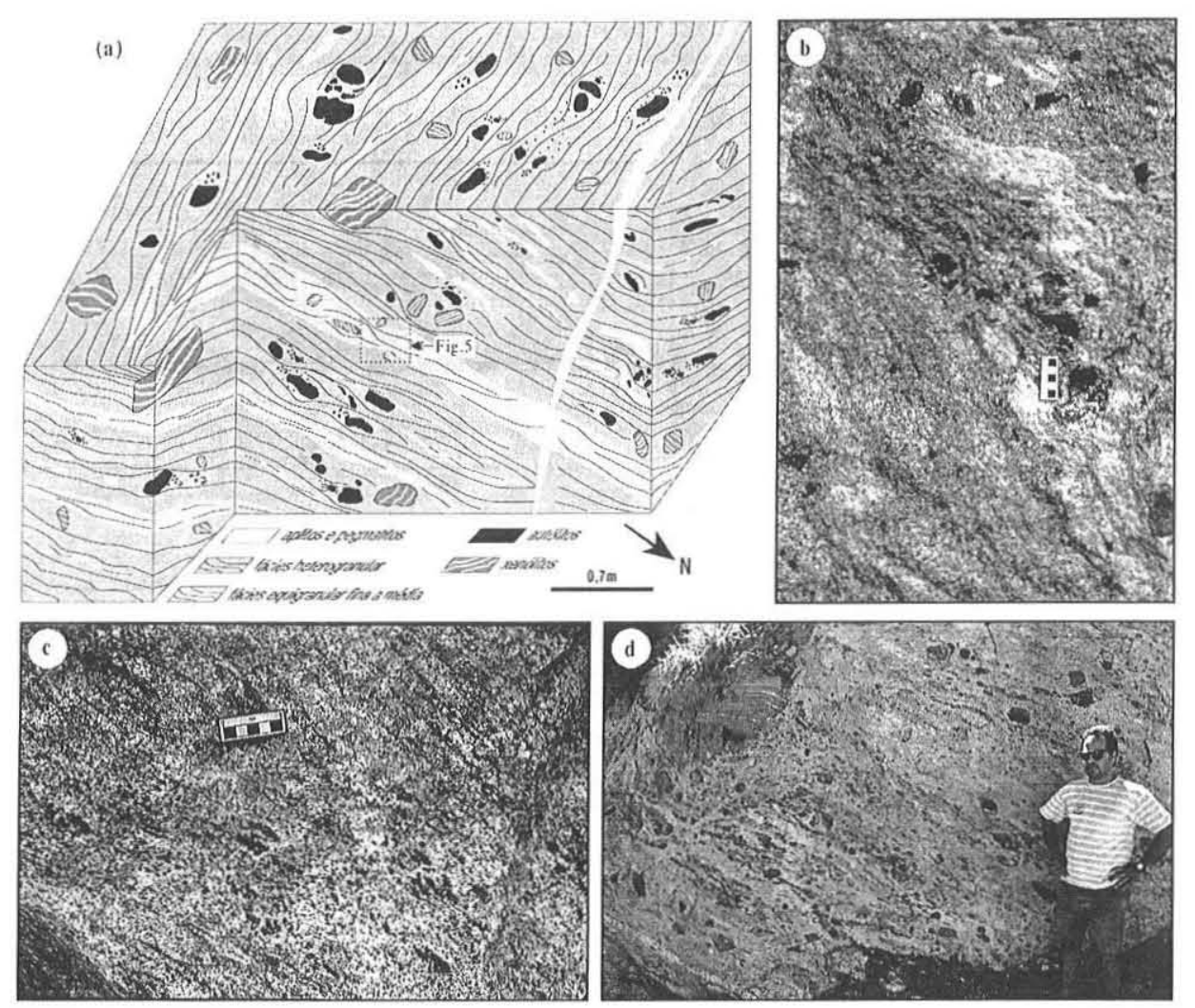

Figura 3 - Feições mesoscópicas do Granito Itapema: (a) croqui esquemático da variação morfológica da foliação, alternância de tipos texturais e composicionais ao longo da estrutura principal e distribuição de autólitos exenólitos; (b) bolsões irregulares de material aplítico-pegmatítico ao longo da foliação de fluxo; (c) foliação de fluxo marcada por trilhas de aglomerados máficos alongados; (d) bandamento de fluxo, mostrando a abundância relativa de enclaves e a regularidade da estrutura.

Tabela I - Proporções modais dos minerais das variedades texturais do Granito Itapema. (1.000 a 1.500 pontos por lâmina).

\begin{tabular}{|c|c|c|c|c|c|c|c|c|c|}
\hline \multirow[b]{2}{*}{ Amostra $n^{\circ}$} & \multicolumn{4}{|c|}{ Fácies equigranular fina } & \multicolumn{5}{|c|}{ Fácies heterogranular } \\
\hline & $13 \mathrm{a}$ & $12 \mathrm{~h}$ & $35 \mathrm{a}$ & $36 \mathrm{a}$ & $35 b$ & $36 \mathrm{~b}$ & $12 \mathrm{a}$ & $12 \mathrm{f}$ & $16 a$ \\
\hline Plagioclásio & 29,7 & 29,1 & 28,9 & 39 & 24,5 & 43,8 & 42,8 & 45,7 & 43,8 \\
\hline K-feldspato & 35,8 & 35,5 & 37.9 & 29 & 34 & 15,7 & 18,7 & 14 & 17,8 \\
\hline Quartzo & 30.5 & 29.3 & 19,6 & 24,2 & 27,2 & 23.9 & 24,6 & 21 & 23,8 \\
\hline Biotita & 3 & 4,1 & 10 & 6,1 & 9 & 11 & 7 & 7,4 & 9 \\
\hline Anfibólio & ....... & $\ldots$ & .... & tr & 0,8 & 2 & 3,4 & 9,1 & 3 \\
\hline Epidoto & 1 & 1 & 1.4 & 1 & 2,9 & 1,6 & 1,6 & 1 & 0,9 \\
\hline Magnetita & 0,3 & 0,4 & 0,5 & 0,2 & 0,6 & 1 & 1 & 0.5 & 0,3 \\
\hline Ilmenita & 0.1 & $\ldots$ & $\ldots$ & $\ldots$ & -.... & $\ldots$ & $\ldots$ & $\ldots$ & … \\
\hline Zircão & 0.5 & 0.5 & 0,3 & 0,3 & 0,2 & 0,6 & 0.6 & 0,4 & 0,7 \\
\hline Titanita & ...... & $\ldots$ & 0,4 & 0,2 & 0,7 & 0,3 & 0,2 & 0,8 & 0,6 \\
\hline Apatita & 0,1 & 0,1 & 0,1 & 0,3 & 0,1 & 0,1 & 0,1 & 0,1 & 0,1 \\
\hline
\end{tabular}

principalmente na fácies heterogranular, contêm às vezes subgrãos relativamente grandes, de limites curvos e desorientação de até $5^{\circ}$. Segundo Bitencourt (1996), esta morfologia é compatível com deformação sob temperatura elevada, pois implica a ativação simultânea de vários sistemas de deslizamento. Esporadicamente, o plagioclásio apresenta kink bands bem desenvolvidas.

O K-feldspato ocorre em ambas fácies como cristais anédricos a subédricos, de contatos nítidos e retos, raramente lobados. Os cristais maiores contêm muitas inclusões de biotita, plágioclásio, zircão, quartzo, apatita e feldspato alcalino. Nos termos equigranulares, contêm também inclusões de albita e magnetita. A pre- sença de macla albita-periclina é rara nos termos heterogranulares e comum nos finos. Micropertitas regulares, finas, do tipo fios ou fitas, com a fase sódica perfazendo cerca de $10 \%$ em volume, são características dos termos heterogranulares, enquanto nos termos finos são mais desenvolvidas e mais abundantes, com proporção da ordem de $15 \%$ em volume e morfologia de fitas e tranças (Fig. 6a). Pertitas em chama ocorrem em ambas as fácies, principalmente nas bordas dos cristais, por vezes seccionando fios e fitas. Esse tipo de pertitas é geralmente interpretado como resultante de deformação no estado sólido, em temperaturas compatíveis com as da fácies xistos verdes (Pryer \& Robin 1996). Raros cristais de K-feldspato têm extinção ondulante forte.

Oquartzo é anédrico, intersticial, com contatos nítidos, lobados ou retos. Em ambas as fácies, sobretudo nos termos equigranulares, é marcante a ocorrência de cristais maiores com forte extinção ondulante, contendo subgrãos do tipo tabuleiro de xadrez, caracterizados por subgrãos prismáticos e basais no mesmo cristal (Fig. 6b). A utilização desta microestrutura como geotermobarômetroé proposta por Kruhl (1996). A posição do eixo-c em relação aos limites de subgrãos foi determinada com auxílio do compensador. Localizadamente, ocorrem faixas estreitas e descontínuas de recristalização marginal do quartzo. Nestas faixas, os novos grãos são geralmente 10 vezes menores que o grão original, e seus contatos são interlobados, sugestivos de recristalização por migração de limites de grãos em baixa temperatura. Estas coroas são mais abundantes nos termos equigranulares finos.

A biotita é castanho-escura em ambas fácies. Nos termos 

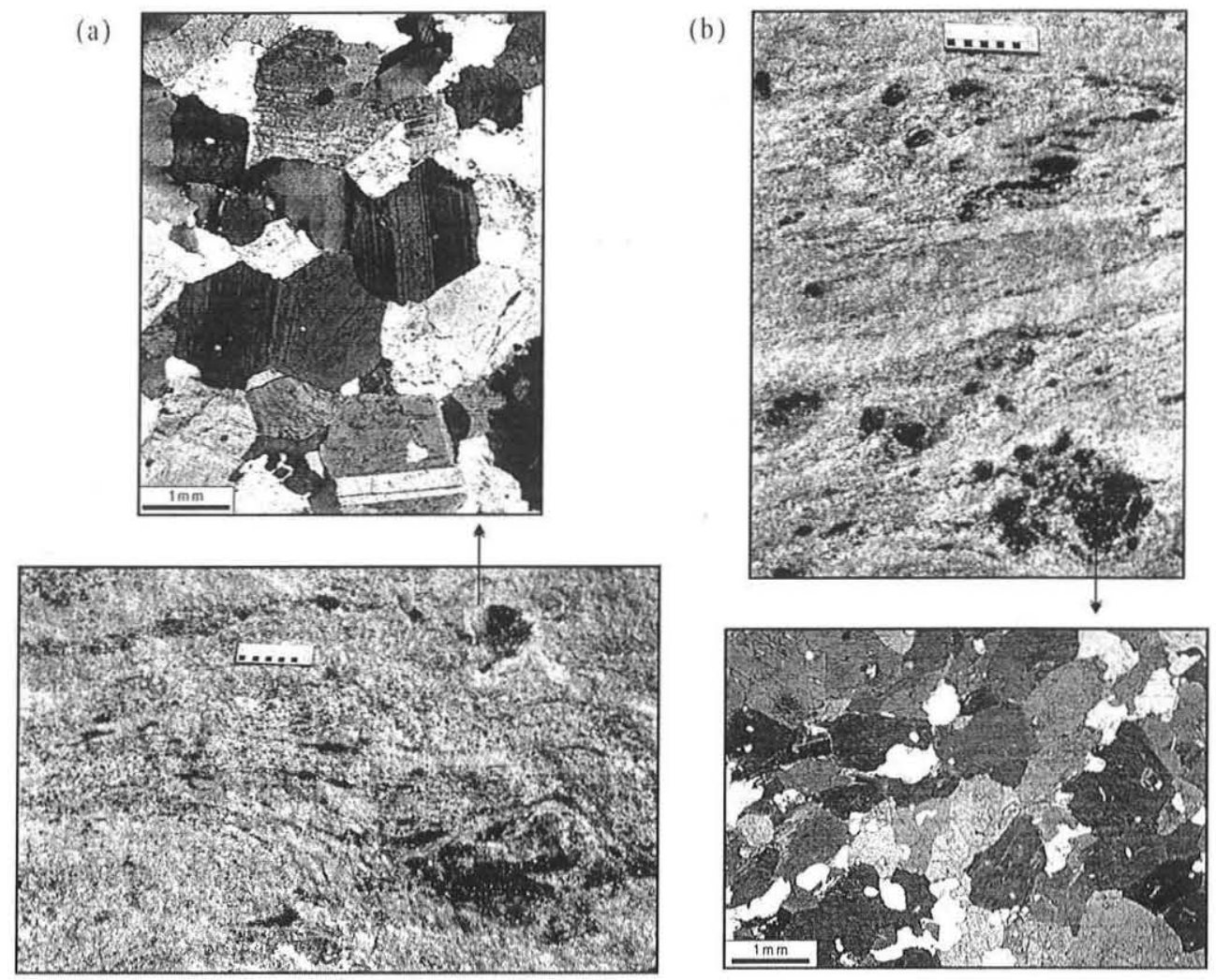

Figura 4 - Aspectos estruturais e texturais do Granito Itapema: (a) estrutura de fluxo realçada por schlieren provenientes da desagregação de autólitos máficos, com formação de cumulatos de plagioclásio (LP) ao redor dos autólitos retrabalhados; (b) alternância irregular de bandas leucomonzograníticas nos termos heterogranulares, que contêm autólitos máficos parcialmente desmembrados pelo fluxo; a textura cumulática $(L N)$ é marcada por cristais cumulus de hornblenda, com feldspatos intercumulus.

heterogranulares, ocorre preferencialmente como cristais precoces, participando de aglomerados máficos (Figs. 6c,d), onde é acompanhada por hornblenda, titanita, epidoto e magnetita. Subordinadamente, ocorre uma geração tardia de biotita, anédrica, intersticial, de contatos retos ou lobados. É comum a ocorrência de lamelas com extremidades esfiapadas, principalmente no contato com fases félsicas, feição interpretada como resultante de cisalhamento ao longo da clivagem. Nos termos equigranulares finos, a biotita forma pequenos agregados arredondados ou alongados, associada a epidoto e magnetita. Feições de cisalhamento ao longo da clivagem são pouco freqüentes. Raras lamelas têm extinção ondulante, com leve encurvamento da clivagem; kink bands são ocasionais. Os cristais contêm poucas inclusões de plagioclásio, epidoto, zircão e magnetita.

A hornblenda é restrita aos termos heterogranulares, como cristais euédricos a subédricos. Seus contatos com a biotita são ora retos e nítidos, de equilíbrio (Fig. 6c), ora irregulares e difusos, reativos (Fig. 6d). A transformação de hornblenda em biotita tem intensidade variável e geralmente envolve a formação de magnetita e epidoto euédrico. Estas relações indicam superposição temporal na cristalização de ambos, em equilíbrio. Os cristais de hornblenda têm poucas inclusões de plagioclásio $\left(\mathrm{An}_{29}\right)$, biotita, zircão, apatita, titanita e magnetita. A quantidade de hornblenda nos aglomerados é maior na proximidade de autólitos máficos, e seus cristais comumente mostram contatos a $120^{\circ}$ (Fig. 5d).

O epidoto ocorre principalmente nos aglomerados máficos, como cristais euédricos de até $0,3 \mathrm{~mm}$, sugestivo de seu caráter primário (Fig. 6c). É também freqüente como coroas de cristais euédricos ao redor de alanita. Cristais anédricos estão associados à transformação incompleta de hornblenda em biotita nos termos heterogranulares (Fig. 6d). De modo localizado, diminutos cristais de epidoto ocorrem como produto de alteração do plagioclásio ou de epidoto precoce.

A titanita é euédrica nos termos heterogranulares e ocorre preferencialmente nos aglomerados máficos (Fig. 6d). Os grãos maiores são, às vezes, envoltos por uma geração de titanita anédrica, fina, provavelmente secundária. Nos termos equigranulares é mais rara e forma cristais euédricos ou anédricos, tardios. A magnetita é euédrica a subédrica, freqüentemente associada a biotita e hornblenda nos aglomerados máficos de ambas as fácies. A ilmenita foi constatada apenas em termos muito diferenciados da fácies equigranular, como coroa ao redor da magnetita. Zircão e apatita são inclusos em plagioclásio, hornblenda e biotita nos termos heterogranulares, e em quartzo, feldspato alcalino, plagioclásio e biotita nos equigranulares finos.

Autólitos Os autólitos mais abundantes são hornblenditos a hornblenda dioritos, com proporções variáveis de plagioclásio e biotita. Autólitos félsicos a base de plagioclásio, são mais raros e compostos de plagioclásio e formam bolsões ou coroas em torno de autólitos máficos ou ultramáficos (Fig. 4a). Independente da composição, estas rochas são equigranulares médias a grossas e têm textura cumulática dada por cristais euédricos de hornblenda (Fig. 4b) ou plagioclásio (Fig. 4a) em contatos a $120^{\circ}$. Nos autólitos 

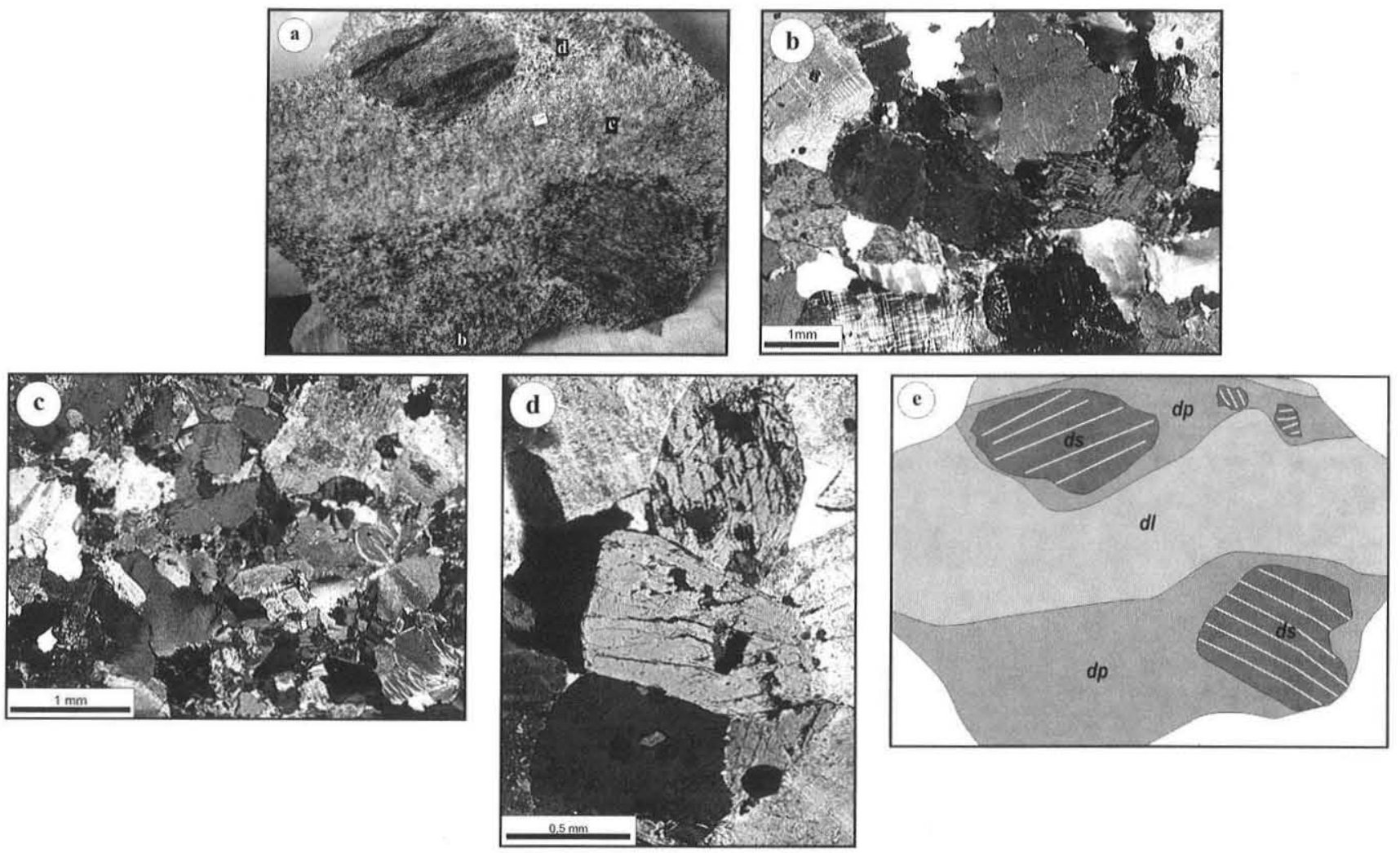

Figura 5 - (a) Amostra locada na figura 3a, mostrando a relação entre as fácies texturais do Granito Itapema; (b) aspecto textural (LP) típico da fácies heterogranular; (c) aspecto textural (LP) típico da fácies equigranular fina a média; (d) textura $(L P)$ de agregados de hornblenda da fácies heterogranular nas proximidades de xenólitos; (e) domínios reológicos identificados no Granito Itapema; ds - domínio sólido, dl -domínio líquido, dp-domínio pasta.

ultramáficos e máficos, o material intercumulus é composto por plagioclásio, K-feldspato e quartzo, e nos autólitos leucodioríticos por quartzo, plagioclásio e pequena quantidade de magnetita.

A orientação preferencial dos constituintes é observada em em diversos autólitos, realçada pela biotita. Entretanto, não se observa deformação interna dos minerais compatível com seu grau de alinhamento dimensional. Subordinadamente há uma estrutura sutíl e descontínua dada por bandas de anfibólio \pm biotita alternadas com bandas de plagioclásio \pm biotita.

A hornblenda é geralmente euédrica e contém poucas inclusões de titanita e plagioclásio $\left(A n_{30}\right)$. Os cristais cumulus de plagioclásio dos autólitos leucodioríticos e hornblenda-dioríticos são euédricos e freqüentemente têm forte zonação normal $\left(\mathrm{An}_{30}\right.$. ${ }_{26}$ ). Contêm poucas inclusões de biotita, magnetita e plagio-clásio. Quandoé parte do material intercumulus, em autólitos ultramáficos ou máficos, o plagioclásio é anédrico e de composição $\mathrm{An}_{29.31}$. A biotita é castanho-escura e pouco abundante. A titanita é euédrica, ocorrendo de modo independente ou como pequenos cristais ao redor de anfibólio ou biotita. Apatita e zircão são euédricos e inclusos em anfibólio e plagioclásio. A magnetita é pouco abundante, mas sua quantidade é ligeiramente maior junto ao contato dos autólitos com o granitóide encaixante.

Xenólitos de anfibolito O estudo petrográfico dos xenólitos do Granito Itapema restringiu-se aos anfibolitos maciços, os quais são, em amostra de mão, texturalmente semelhantes aos autólitos máficos e ultramáficos. As principais diferenças em afloramento são seus contatos retos com as encaixantes e a tendência a ocorrer em blocos mais angulosos não alinhados. Os anfibolitos têm textura granoblástica média e são compostos por hornblenda e clinopiroxênio, subordinadamente quartzo e feldspato finos.

A hornblenda é a fase mais abundante e contém abundantes inclusões globulares de quartzo e feldspatos, zircão e opacos. O clinopiroxênio está, em grande parte, substituído por actinolita.

QUÍMICA MINERAL Variação composicional dos minerais FELDSPATOS A variação composicional do plagioclásio se sobrepõe nos diferentes termos composicionais e texturais investigados (Fig. 7). Na fácies heterogranular, a composição varia de oligoclásio a andesina $\left(\mathrm{An}_{20}\right.$ a $\left.\mathrm{An}_{32}\right)$ e nos termos equigranulares predomina oligoclásio $\left(\mathrm{An}_{12}\right.$ a $\left.\mathrm{An}_{30}\right)$, com albita subordinada. $\mathrm{A}$ composição do plagioclásio dos autólitos hornblendíticos e leucodioríticos é pouco variável e situada no intervalo dos termos graníticos menos diferenciados $\left(\mathrm{An}_{31}\right.$ a $\left.\mathrm{An}_{26}\right)$. Não há diferença composicional entre cristais cumulus e intercumulus. O Kfeldspato homogêneo tem composição média $\mathrm{Or}_{93.97} \mathrm{Ab}_{7.3}$, com $0,1 \%$ a $1 \%$ de $\mathrm{BaO}$.

BIOTITA A variação composicional da biotita do Granito Itapema reflete as relações petrográficas observadas nos diferentes termos texturais. A Tabela 2 contém dados de análise química e fórmulas estruturais representativas da variação composicional, acompanhadas de sua interpretação textural nas fácies heterogranular, equigranular fina a média e nos autólitos máficos. 

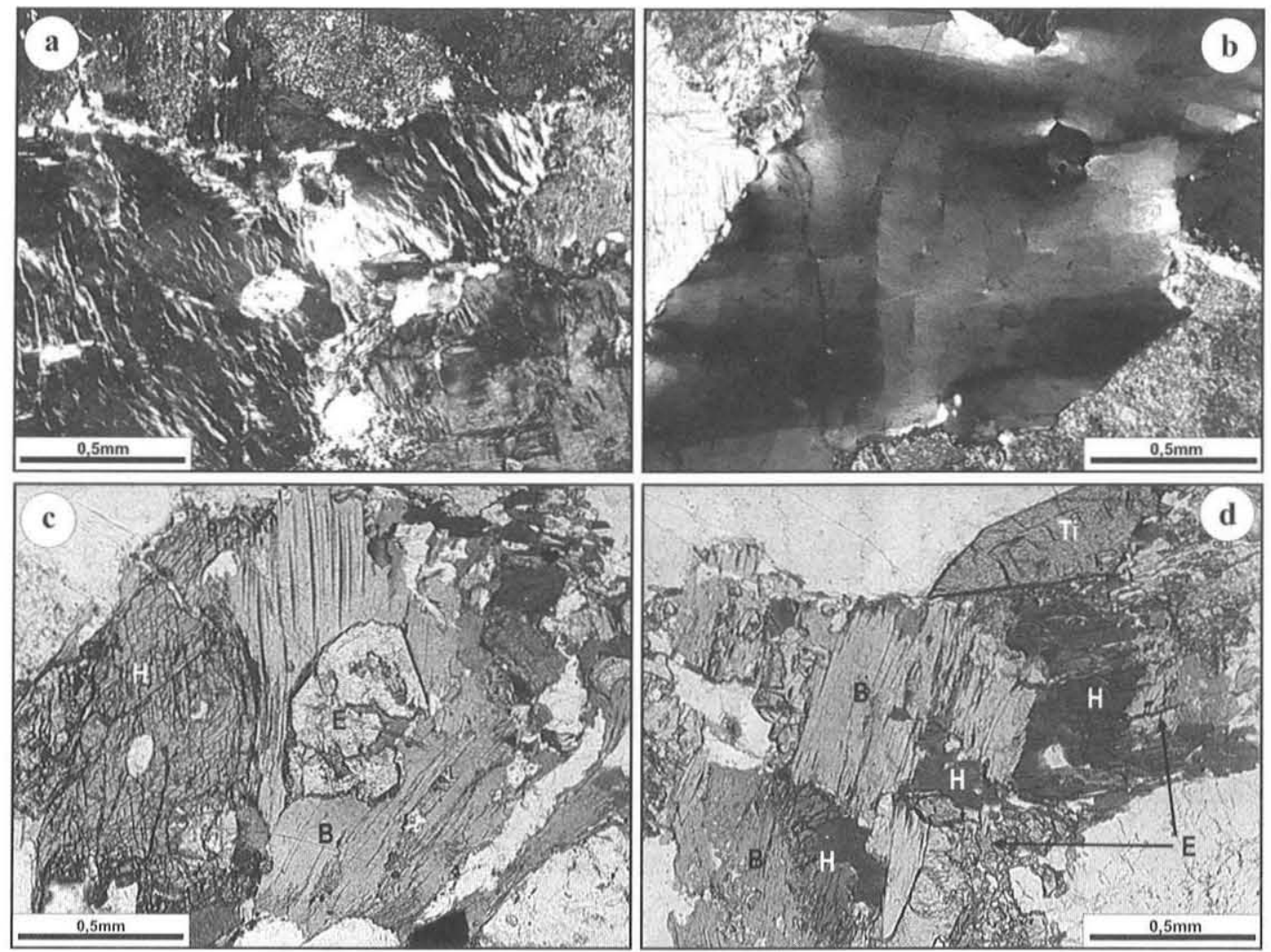

Figura 6 - Feições petrográficas do Granito Itapema - fotomicrografias (a) e (b) em luz polarizada, (c) e (d) a luz natural. H hornblenda, B - biotita, E- epidoto, Ti - titanita. (a) K-feldspato com micropertitas do tipo fios e tranças nos monzogranitos da fácies equigranular fina a média; (b) quartzo com subgrãos do tipo tabuleiro de xadrez; (c) contatos de equilíbrio entre biotita, hornblenda e epidoto euédrico em aglomerado máfico da fácies heterogranular; (d) contatos reativos entre biotita, hornblenda e epidoto em aglomerado máfico da fácies heterogranular:

A biotita precoce da fácies heterogranular (fh) se destaca da tardia por teores mais baixos de $\mathrm{Al}$ '. A razão \#fm $\left\{\mathrm{Fe}^{+2} /\left(\mathrm{Fe}^{+2}+\right.\right.$ $\mathrm{Mg}$ )\} tende a ser menor (Fig. 8), bem como os teores de $\mathrm{Si}^{\mathrm{iv}}$ e $\mathrm{Mg}$ (Fig. 9e 10). A biotita precoce é similar à dos autólitos máficos na razão\#fme teores de $\mathrm{Mg} \mathrm{e} \mathrm{Al}^{\prime}$ (Figs. 8 e 10), mas difere pelo teor mais elevado de $\mathrm{Si}^{\mathrm{iv}}$ (Fig. 9).

A biotita da fácies equigranular constitui duas populações distintas, relacionadas ao grau de diferenciação da rocha. Nos termos menos diferenciados, a razão \#fm e os teore de Al', $\mathrm{Si}^{\mathrm{iv}} \mathrm{e}$ Mg são identicos aos dos cristais tardios (Fig. 8, 9 e 10). Nos termos mais diferenciados, a biotita se destaca das demais pelos valores maiores de $\mathrm{Al}^{\prime} \mathrm{e} \# \mathrm{fm}$ (Fig. 8), com teores de $\mathrm{Si}^{\mathrm{i}}$ e $\mathrm{Mg}$ mais baixos (Figs. 9e 10).

A figura 10 mostra os extremos composicionais teóricos com relação a Mg e Al', utilizados por Nachit et al. (1985) para discriminar biotitas de diferentes séries magmáticas. Segundo estes parâmetros, as biotitas do GI tapema são compatíveis com as das suítes magmáticas cálcio-alcalinas, desenvolvendo um trend de diferenciação próximo da linha flogopita-siderofilita.

ANFIBÓLIO Análises representativas de anfibólio do Granito Itapema, autólitos máficos e xenólitos de anfibolito, acompanhadas de sua interpretação textural constam na Tabela 3. Os anfibólios são variedades cálcicas (Fig. 11|) na classificação de Leake et al (1997), com razão catiônica $\mathrm{Mg} /\left(\mathrm{Mg}+\mathrm{Fe}^{+2}\right)>0,5$. Na fácies heterogranular é magnésio-hornblenda a tschermakita, com Siv entre 6,4 e 6,7 átomos por unidade de fórmulas (auf). Nos autólitos máficos, a proporção de $\mathrm{Fe}^{+2} \mathrm{e} \mathrm{Mg}$ é similar à do anfibólio da fácies heterogranular, mas sua variação composicional é menor, ocorrendo apenas magnésio-hornblenda. Nos xenólitos de anfibolito, $\mathrm{o}$ anfibólio se destaca pela elevada razão catiônica $\mathrm{Mg}$ / $\left(\mathrm{Mg}+\mathrm{Fe}^{+2}\right)$, acompanhada de altos valores de $\mathrm{Si}^{\mathrm{iv}}$, embora também se classifique como magnésio-hornblenda. O anfibólio dos xenólitos também difere pelos teores de $\mathrm{Fe}^{+3}$, Ti e $\mathrm{Al}^{1}$ menores do que os das encaixantes.

Nos termos heterogranulares, foram analisados centro e borda de alguns cristais de anfibólio sem zonação ótica. A variação mais significativa é a diminuição do teor de $\mathrm{Al}^{\prime}$ em direção à borda, com comportamento variável do teor de $\mathrm{Fe}^{+3}$ calculado. Nos anfibólios dos autólitos e da fácies heterogranular, há forte correlação negativa entre $\mathrm{Si}^{\mathrm{i}} \mathrm{e} \mathrm{Al}^{\prime}$, nos autólitos tendendo a valores mais elevados de $\mathrm{Si}^{i v}$ e mais baixo $\mathrm{Al}^{1}$.

EPIDOTO Apenas os cristais de epidoto com feições petrográficas sugestivas de caráter primário foram estudados quimicamente, tanto nos termos heterogranulares como nos equigranulares. Os resultados analíticos indicam a semelhança composicional do epidoto de ambas as fácies, caracterizado por teores relativamente elevados de $\mathrm{Fe}^{+3}$ ( 1,5 a 2,0auf), com proporção de pistacita $\left\{\mathrm{Ps}=\mathrm{Fe}^{+3} /\left(\mathrm{Fe}^{+3}+\mathrm{Al}\right)\right\}$ em torno de 0,29.

MINERAIS OPACOS A composição da magnetita de todas as 


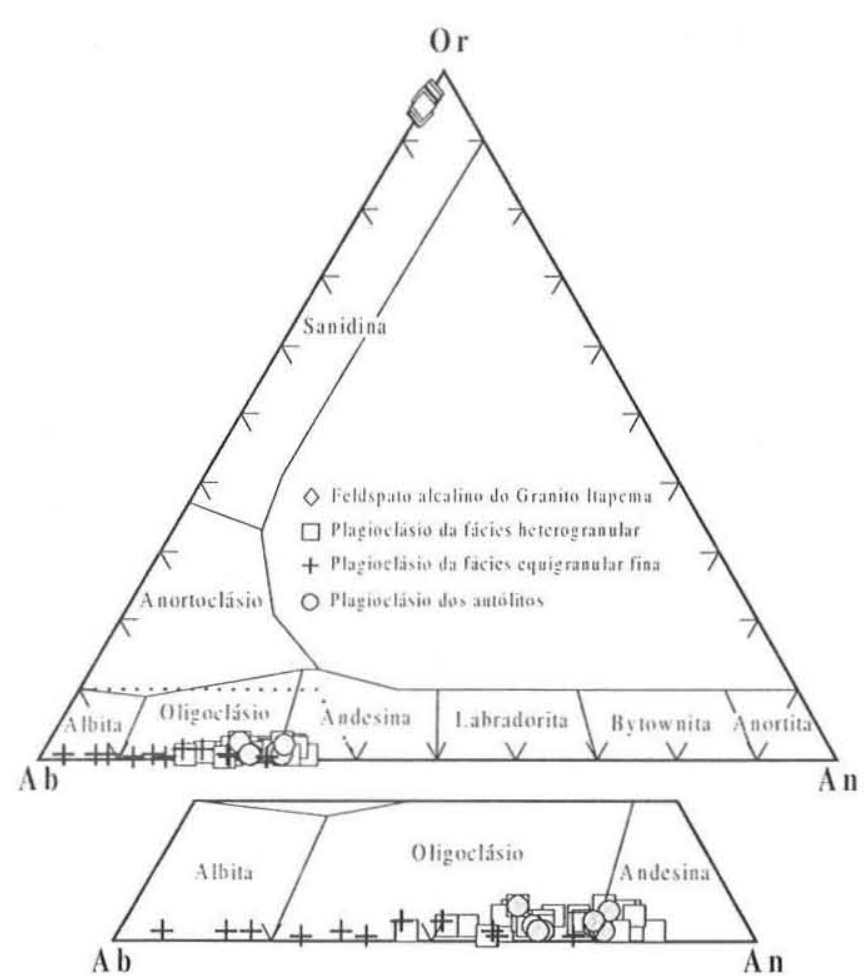

Figura 7 - Feldspatos do Granito Itapema plotados no diagramaAb-An-Or:

variedades petrográficas estudadas é homogênea, com teores muito baixos de $\mathrm{TiO}_{2} \mathrm{eFe}_{2} \mathrm{O}_{3}$ entre 68 e $69 \%$. A ilmenita, presente somente nos termos mais diferenciados da fácies equigranular, tem teores de $\mathrm{FeO}$ em torno de $40 \%$ e $\mathrm{TiO}_{2}$ entre 50 e $53 \%$.

Implicações dos resultados A integração dos dados geológicos, petrográficos e de química mineral do GI aponta para a evolução dos termos composicionais a partir de um mesmo magma. Estes também indicam que os anfibólio-biotita granodioritos da fácies heterogranular representam os termos menos diferenciados. Os biotita monzogranitos da fácies equigranular são termos progressiva-mente mais diferenciados, cujo extremo é representado por leuco-monzogranitos (Tabela 1). Dados geoquímicos de Bitencourt \& Nardi (2004) demonstram a evolução comum destas rochas a partir de um mesmo magma e confirmam o caráter mais diferenciado dos termos da fácies equigranular fina a média, dado pelos teores menores de $\mathrm{FeO}^{\mathrm{T}}, \mathrm{MgO}_{\text {e } \mathrm{CaO}}$.

Os dados petrográficos e a composição dos minerais máficos indicam cristalização precoce de anfibólio, seguida de anfibólio + biotita e finalmente apenas biotita, em quantidade decrescente. A razão catiônica \#fm destes minerais aumenta com a diferenciação do magma, o que é observado sobretudo na composição da biotita, por seu aumento de alumínio no mesmo sentido. A biotita dos termos com magnetita tem razão catiônica \#fm de 0,5 , inferior à da rocha total $(0,7)$, e nas rochas com ilmenita ambos valores se aproximam. A maior quantidade de magnetita nas fácies heterogranular e equigranular, e sua escassez nos autólitos, indica que o potencial de oxidação do magma cresceu durante o início da evolução do sistema. A presença de ilmenita nos termos mais diferenciados da fácies equigranular pode resultar da perda de voláteis, que levaria à redução do potencial de oxidação.

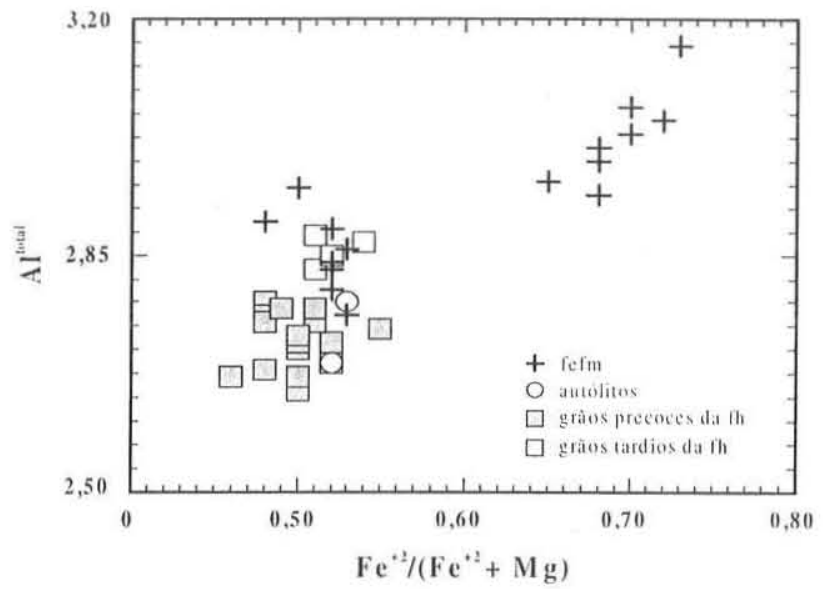

Figura 8 - Diagrama de variação de Al' versus \#fin de biotita do Granito Itapema; fefin - fácies equigranular fina a média; fh fácies heterogramular:

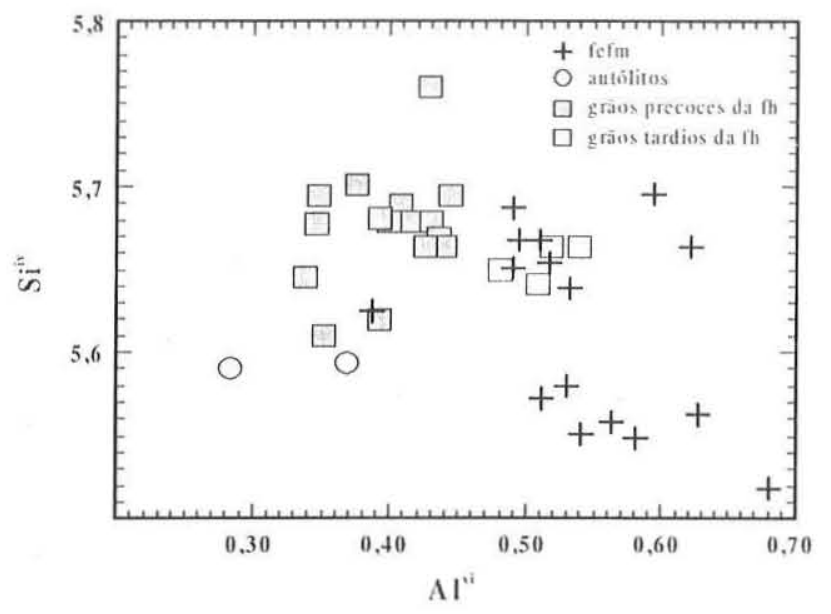

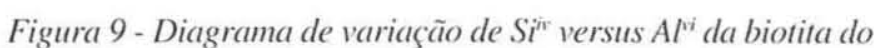
Granito Itapema. Símbolos como na figura 8.

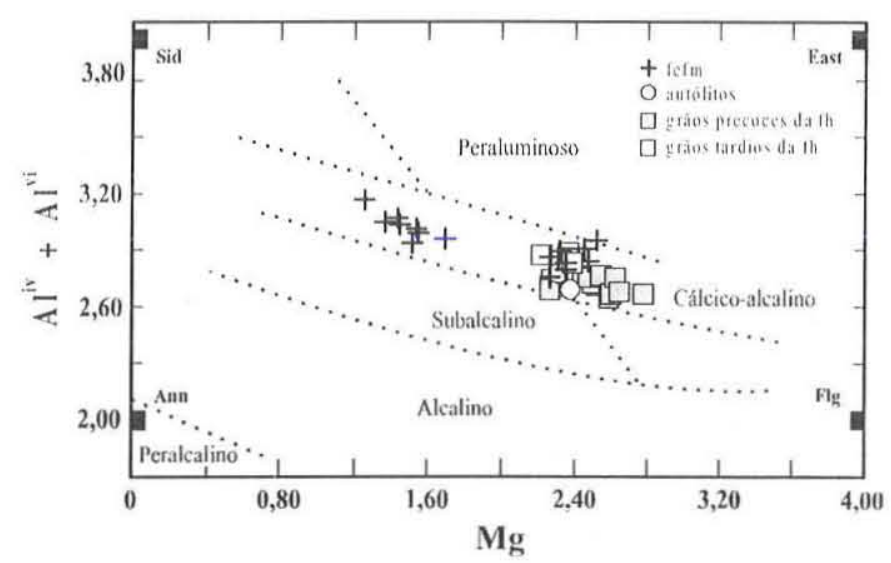

Figura 10 - Diagrama de variação de Al' versus $\mathrm{Mg}$ de biotita do Granito Itapema, com os campos delimitados de acordo com Nachitt et al. (1985). Extremos teóricos Flogopita (Flg), Eastonita (East), Annita (Ann) e Siderofilita (Sid) indicados. Símbolos como na figura 8. 
A proporção de pistacita do epidoto, em média 0,29 , aliada a suas características petrográficas, sugere sua gênese magmática. Segundo Vyhnal et al. (1991), teores de pistacita entre 0,25 e 0,3 são característicos de epidoto magmático e indicam condições de pressão superiores a 3,3 kbar, se considerado o potencial de oxidação indicado pela pesença de magnetita. A presença de epidoto magmático também sugere concentrações de água no líquido mag 'matico próximas da saturação.

O teor de An do plagioclásio de autólitos hornblendíticos e dioríticos é relativamente baixo para plagioclásios cristalizados a partir de líquidos desta composição, o que reforça a hipótese da origem cumulática destes autólitos.

PETROGÊNESE Parâmetros físicos Os dados aqui obtidos, integrados com os de Bitencourt \& Nardi (2004) permitem estimar as condições físicas de cristalização do Granito Itapema. Os resultados obtidos constam na Tabela 4.

CÁLCULO DA PRESSÃO Segundo Hammarstrom \& Zen (1986), revisto por Vyhnal et al. (1991), o teor de alumínio total da hornblenda pode ser utilizado como geobarômetro em rochas de afinidade cálcio-alcalina, na presença de equilíbrio da associação quartzo + hornblenda + plagioclásio sódico + K-feldspato + biotita + magnetita + titanita + epidoto. Uma vez que a entrada de Al na estrutura do anfibólio é favorecida em temperatura mais alta, os valores representativos das condições de pressão são os determinados na borda dos cristais estudados, que indicam pressão do sistema próximo à temperatura da curva solidus.

Adotando a formulação de Schmidt (1992) para o geobarômetro $\mathrm{Al}^{\prime}$ - Hb, em condições saturadas, obteve-se uma pressão de cristalização dos anfibólios do Granito Itapema entre 3,84 e 4,7 \pm 0,6kbar:

CÁLCULOS DE TEMPERATURA Aplicando a fórmula de Watson \& Harrison (1983) para os conteúdos de zircônio em amostras analisads por Bitencourt \& Nardi 2004), a temperatura do magma do Granito Itapema situa-se entre 740 e $805^{\circ} \mathrm{C}$, interpretado como próximo da temperatura liquidus do sistema, uma vez que o zircão é uma fase precoce nestas rochas.

A composição do par hornblenda-plagioclásio foi utilizada para determinar a temperatura do sistema próximo da curva solidus, segundo o geotermômetro de Holland \& Blundy (1994). O emprego deste geotermômetro se restringe a temperaturas entre $500 \mathrm{e} 900^{\circ} \mathrm{C}$, composição de plagioclásio com $0,1<\mathrm{X}_{\mathrm{an}}<0,9$, anfibólio com $\mathrm{X}_{\mathrm{Na}}$ $>0,03$ auf, $\mathrm{Al}^{\mathrm{vi}}<1$.8auf e $\mathrm{Si}^{\mathrm{iv}}$ entre 6,0 e 7,7 auf, com ou sem quartzo. Para avaliar a condição de equilíbrio do par anfíbólio-plagioclásio, foram utilizadas as relações texturais e a correlação entre a razão $\mathrm{Na} / \mathrm{Ca}$ no sítido $\mathrm{B}$ da hornblenda e a razão $\mathrm{Na}$ /Ca do plagiocásio, como sugere Spear (1980).

Por este método, o intervalo de temperatura do magma do Gi é de 700 a $748^{\circ} \mathrm{C}\left( \pm 35-40^{\circ} \mathrm{C}\right)$. Comparando este intervalo com o obtido a partir da saturação do zircônio, estima-se que o magma cristalizou ente 805 e $700^{\circ} \mathrm{C}$.

A presença de subgrãos prismáticos no quartzo implica ativação em sistema de deslizamento basal-a, que pode ocorrer a partir de $300^{\circ} \mathrm{C}$. Entretanto, a ativação do sistema prismático-c exige temperaturas muito altas (Mainprice et al. 1986) e sua ocorrência nas estruturas do tipo tabuleiro de xadrez é utilizada por Kruhl (1996) como geotermobarômetro. Empregando os resultados do geobarômetro Al'-Hb no diagrama proposto por Kruhl (1996) para estimar a temperatura de formação destes subgrãos no quartzo do

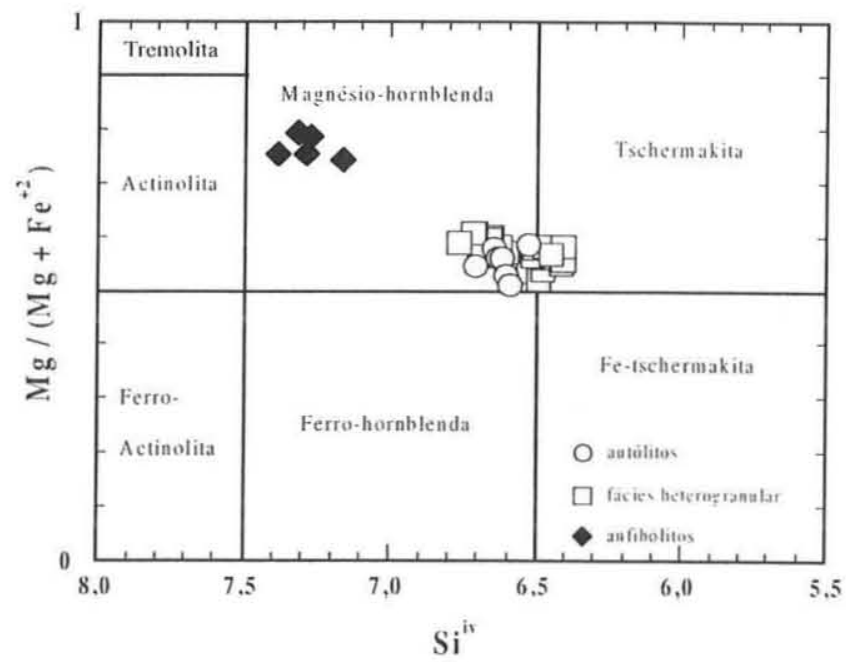

Figura 11 - Classificação dos anfibólios do Granito Itapema e de xenólitos de anfibolito conforme Leake et al.(1997).

Granito Itapema, sob pressão de 3,84 a 4,7kbar obtêm-se temperaturas de $665^{\circ} \mathrm{Ca} 691^{\circ} \mathrm{C}$.

CÁLCULOS DE VISCOSIDADE A presença de epidoto e anfibólio precoces permite estimar uma quantidade inicial de 4 a $5 \%$ em peso de água no magma do GI. Considerando a incompatibilidade da água durante a cristalização, e sua curva de solubilidade sob pressão da ordem de 4 a 4,5 kbar, estima-se que o teor de água nos líquidos mais evoluídos teria sido da ordem de 8 a $9 \%$ em peso.

Os valores de viscosidade natural $\left(\eta_{0}\right)$ e efetiva $\left(\eta_{\mathrm{e}}\right)$ do magma do Granito Itapema resultam da aplicação das relações propostas por Bottinga \& Weill (1972) e Roscoe (1952) para avaliar os efeitos da composição, temperatura e teor de cristais do sistema.

Para investigar a variação de viscosidade do GI, empregaramse resultados de análises químicas de rocha total obtidos por Bitencourt \& Nardi (2004) representativos dos termos heterogranulares e equigranulares, com diferentes graus de diferenciação (Tabela 5). Os valores de viscosidade foram calculados a partir das análises químicas, considerando pressão média de $4 \mathrm{kbar}$, teor de água entre 0 e $8 \%$, temperatura entre $850^{\circ} \mathrm{e}$ $700^{\circ} \mathrm{C}$ e fração sólida $(\Phi)$ de 0 a 0,7 .

Nas rochas com anfibólio, um referencial de $4 \%$ de água resulta em valores de $\eta_{0}$ entre $10^{4}$ e $10^{5} \mathrm{~Pa}$.s a $850^{\circ} \mathrm{C}$, respectivamente para os termos menos e mais diferenciados. Nas mesmas condições de temperatura, o efeito do maior grau de diferenciação dos líquidos mais evoluídos, representados nas rochas da fácies equigranular, é compensado pelo aumento do teor de água, o que resulta em valores de viscosidade da mesma ordem.

Para a composição menos diferenciada de líquidos capazes de cristalizar anfibólio, teores de água decrescentes a partir de $4 \%$ e temperaturas entre $800^{\circ}$ e $700^{\circ} \mathrm{C}$, o aumento progressivo da fração sólida causa uma variação de viscosidade efetiva de $10^{5} \mathrm{~Pa} . \mathrm{s}$, para $\Phi=0,1$, ate $10^{8}$ Pa.s, quando $\Phi$ atinge 0,7 . Em composicões mais diferenciadas, nas mesmas condições, a viscosidade efetiva varia entre $10^{5}$ e $10^{\circ}$ Pa.s.

Para as composições mais diferenciadas de líquidos compatíveis com as rochas equigranulares, tomando-se como referencial teor de água decrescente a partir de $8 \%$ (próximo da saturação) e temperaturas entre $800^{\circ} \mathrm{e} 700^{\circ} \mathrm{C}, \mathrm{o}$ aumento progressivo da fração 
Tabela 4 - Condições de temperatura e pressão determinadas para a cristalização do Granito Itapema.

\begin{tabular}{|c|c|c|c|c|}
\hline $\begin{array}{c}\text { Temperatura } \\
(\text { ("C) }\end{array}$ & Mínima & Máxima & $\begin{array}{c}\text { Margem } \\
\text { de erro }\end{array}$ & Referência \\
\hline Solubilidade do $\mathrm{Z}$ & 74() & 805 & $\ldots$ & Watson \& Harrison (1983 \\
\hline Homblenda-plagieclásio & $7(x)$ & 748 & $\pm 35 / 40)$ & Holland \& Blundy $(19 x) 4)$ \\
\hline Qtautzochessolomed & 605 & $(t) \mid$ & $\ldots . .$. & Kruhl $(\mid Y \%(6)$ \\
\hline \multicolumn{5}{|l|}{$\begin{array}{l}\text { Prexsĩo } \\
\text { (klair) }\end{array}$} \\
\hline 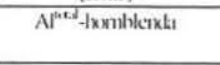 & 3.84 & 4.7 & \pm 0.6 & $\begin{array}{c}\text { Schumidt }(1(X) 2) \\
\text { Anderson \& Smith (19)5) }\end{array}$ \\
\hline
\end{tabular}

sólida causa uma variação de $\eta_{\mathrm{c}}$ de $10^{4}$, para $\Phi=0,1$, até $10^{8}$, pressupondo ainda $2 \%$ de água no sistema, e $10^{\circ}$, para condição anidra, quando $\Phi$ atinge 0,7 .

Os valores de viscosidade calculados são estimativos, uma vez que o sistema depende de muitas variáveis que não são quantitativamente controláveis. Entretanto, os valores obtidos evidenciam variações de viscosidade de até quatro ordens de magnitude, que gerariam significativos gradientes de velocidade do magma na câmara. Também evidenciam a mobilidade dos termos mais diferenciados, devida à concentração de água nos mesmos.

Integração dos dados e modelo petrogenético Os dados préexistentes sobre o Granito Itapema sugerem que o mesmo se originou por fusão crustal, sob condições catazonais, sem a presença de magma básico associado, e tardiamente à tectônica tangencial dos gnaisses encaixantes, durante o Paleoproterozóico.

Os dados aqui obtidos permitem delimitar as condições de pressão litostática de 4 a 4,5 kbar, e da temperatura liquidus acima de $800^{\circ} \mathrm{C}$. A quantidade inicial de água no sistema foi da ordem de 4 a $5 \%$ em peso, atingindo valores de 8 a $9 \%$, próximo da saturação, nos líquidos mais cvoluídos. A formação de magnetita durante toda a cristalização demonstra alto potencial de oxidação do magma durante a maior parte da sua evolução, e a formação localizada de ilmenita em termos muito diferenciados atesta uma mudança destas condições, possivelmente devida ao escape de fluidos, como sugere a bundância de aplitos e pegmatitos tardios. A viscosidade natural dos líquidos magmáticos era da ordem de $10^{4}$ a $10^{5} \mathrm{~Pa} . \mathrm{s}$, sendo os efeitos da diferenciação compensados pela concentração da água nos líquidos mais evoluídos.

A abundância de xenólitos de tamanho e composição variados sugere que o sistema não se deslocou por grandes distâncias a partir da origem. A presença de xenólitos no líquido magmático responde por gradientes de temperatura e de velocidade do sistema, favorecendo o acúmulo de cristais precoces preferencialmente nas zonas de sombra ou em torno dos xenólitos. Os termos cumuláticos resultantes constituem hornblenditos e leucodioritos, com titanita e zircão. O fluxo, atestado pela foliação do granito, ocasionou a segregação do material acumulado, gerando os autólitos. Ao mesmo tempo, o próprio fluxo foi responsável pelo retrabalhamento dos cumulatos, gerando novas acumulações e desmembrando as previamente formadas. Estes fragmentos foram novamente incorporados ao fluxo, resultando na formação de schlieren que realçam a foliação. Neste cenário, geram-se gradientes reológicos e de hidratação, variações composicionais e químico-mineralógicas num sistema quimica e fisicamente heterogêneo.

Neste sistema heterogêneo, são admitidos três domínios físicos (Fig. 5e): (i) sólido, constituído por xenólitos e autólitos, ainda que os últimos possam conter cerca de 5 a $30 \%$ de líquido intercumulus; (ii) domínio pasta, um susbsistema com ampla variação na razão líquido/cristais e conseqüente variação contínua de viscosidade de até três ordens de magnitude, composicionalmente diversificado devido à variação nas proporções de hornblenda e plagioclásio acumulados ao final da cristalização, nos termos da fácies heterogranular; (iii) domínio líquido, sempre mais diferenciado, cujo baixo teor de cristais e elevada concentração de água tendem a manter a viscosidade relativamente baixa, permitindo o seu deslocamento através das demais, com a conseqüente variação temporal e espacial de sua trajetória de. Embora o sistema como um todo evolua no sentido do comportamento sólido, a distribuição heterogênea dos domínios faz com que esta evolução se superponha no espaço e no tempo.

Integrando os dados termométricos do padrão tabuleiro de xadrez do quartzo e do par hornblenda-plagioclásio com as evidências texturais da cristalização deste último, próxima da temperatura solidus do sistema, estima-se que esta temperatura seja de aproximadamente $680^{\circ} \mathrm{C}$, o que é coerente com os dados experimentais de Nekvasil (1988) para sistemas graníticos em condições físicas similares.

Abaixo da temperatura solidus não há evidências de deformação intensa do Granito Itapema, uma vez que as feições de recristalização em baixa temperatura se restringem a zonas de cisalhamento discretas e de pequeno porte, relacionadas ao posicionamento dos granitóides neoproterozóicos.

\section{' CONSIDERAÇÕES FINAIS E CONCLUSÕES Os dados} geoquímicos pré-existentes, tomados em conjunto com os aqui apesentados permitem sugerir que a variação composicional e textural do Granito Itapema resulta do fracionamento de proporções variáveis de anfibólio e plagioclásio ao longo da cristalização, através do mecanismo de segregação por fluxo. Esta gerou, em certos locais, acumulações precoces, que formaram autólitos.

As variações texturais, composicionais e estruturais pemitem visualizar a evolução magmática do granito em domínios reológicos que, em função de sua distribuição heterogênea, apresentam também relações temporais diversas. Os domínios se traduzem nos principais litotipos, isto é, nos autólitos e xenólitos e nas fácies heterogranular e equigranular fina a média.

O caráter tardi-orogênico do Granito Itapema e a ausência de magma básico associado sugerem orogênese ensiálica, na presença de metamorfismo de fácies granulito paleoproterozóico, o que é confirmado pela idade do segundo metamorfismo de alto grau do Complexo Granulítico de Santa Catarina, referido por Harara (2001).

Agradecimentos Ao apoio financeiro do PRONEX e CNPq (Proc. $n^{\circ} 471584 / 2001-0$ ), à bolsa de pós-graduação concedida à primeira autora pelo CNPq e ao Curso de Pós-graduaçã̃o em Geociências da UFRGS. Aos revisores da RBG pelas sugestões ao manuscrito.

\section{Referências}

Basei M.A.S. 1985. O Cinturão Dom Feliciano em Santa Catarina. Tese de Doutoramento, Instituto de Geociências, USP, 195p.
Basei M.A.S. 1990. O Grupo Brusque: Uma evolução monocíclica? In: SBG, Congr: Bras. Geol., 36, Anciis, 6:2649-2657. 
Basei M.A.S., Siga Jr O., Masquelin H., Harara O.M., Reis Neto J.M. Preciozzi Porta, F. 2000. The Dom Feliciano Belt and the Rio de la Plata Craton: tectonic evolution and correlation with similar provinces of southwestern Africa. In: U.G.Cordani, E.J.Milani , A.Thomaz Filho. D.A.Campos (eds.). Tectonic Evolution of South America. 31st Intern. Geol. Congr., Rio de Janeiro, pp.311-334.

Bitencourt M.F. 1996. Granitóides Sintectônicos da Região de Porto Belo, SC: uma abordagem petrológica e estrutural do magmatismo em zonas de cisalhamento. Tese de Doutoramento, Instituto de Geociências, UFRGS, $310 \mathrm{p}$.

Bitencourt M.F., Hackspacher P.C., Nardi, L.V.S. 1989. A Zona de Cisalhamento Major Gercino - Santa Catarina. In: SBG, Simp. Nac. Est. Tect., 2, Atas, p. 214-216.

Bitencourt M.F.\& Nardi L.V.S. 2000. Tectonic setting and sources of magmatism related to the Southern Brazilian Shear Belt. Rev: Bras. Geoc., 30:186-189.

Bitencourt M.F. \& Nardi L.V.S. 2004. The role of xenoliths and flow segregation in the genesis and evolution of the paleoproterozoic Itapema Granite, a crustally-derived magma of shoshonitic affinity from southern Brazil. Lithos, 73:1-19.

Bottinga Y. \& Weill D.F. 1972. The viscosity of magmatic silicate liquids: a model for calculation. Am. J. Sci., 272:438-475.

Caldasso A.L.S., Krebs A.S.J., Silva M.A.S., Camozzato E., Ramgrab G.E. 1995. Programa Levantamentos Geológicos Básicos do Brasil. Brusque - Folha SG22-Z-D-II-1. Estado de Santa Catarina. Brasília. CPRM. 243p.

Hammarstrom J.M. \& Zen E. 1986. Aluminium in hornblende: an empirical igneous geobarometer: Am. Mine, 71: 1297-1313.

Harara O.M.M. 2001. Mapeamento e Investigaşão Petrológica e Geocronológica dos Litotipos da Região do Alto Rio Negro (PR-SC): um exemplo de sucessivas e distintas atividades magmáticas durante o Neoproterozóico III. Tese de Doutoramento, Instituto de Geociências, USP, 206p.

Hartmann L.A., Bitencourt M.F., Santos J.O.S., McNaughton N.J., Rivera C.B., Betiollo L. 2003. Prolonged Paleoproterozoic magmatic participation in the Neoproterozoic Dom Feliciano Belt, Santa Catarina, Brazil, based on zircon U-Pb SHRIMP geochronology. J. South Am. Earth Sci.. 16:477-492.

Hartmann L.A.. Silva L.C., Orlandi F' V. 1979. Complexo Granulítico de Santa Catarina - Descrição e implicaçōes genéticas. Acta Geol. Leop. 6:93-112.

Holland T. \& Blundy J. 1994. Non-ideal interactions in calcic amphiboles and their bearing on amphibole-plagioclase thermometry. Contrib. Mineral. Petrol., 116: 433-447.

Kruhl J.H. 1996. Prism-and basal-plane parallel subgrain boundaries in quartz: a microstructural geothermobarometer. J. Metam. Geol., 14:581-589

Leake B.E., Wooley A.R., Arps C.E.S., Birch W.D., Gilbert M.C., Grice J.D., Hawthoene F.C., Katto A., Kisch H.J., Krivovichev V.G., Linthout K., Laird J., Mandarino J.A., Maresh W.V., Nickel E.H., Rock N.M.S., Schumacher J.C., Smith D.C., Stephenson N.C.N., Ungaretti L., Wittaker E.J.W., Youzhi G. 1997. Nomenclature of amphiboles: report of the Subcommittee on Amphiboles of the International Mineralogical Association, Comission on New Minerals Names, Am. Miner, 82: 1019-1037.

Mainprice D., Bouchez J.L., Blumenfeld P.,Tubia J.M. 1986. Dominant $c$-slip in naturally deformed quartz: implications for dramatic plastic softening at high temperature. Geology, 14:819-822.

Nachitt H., Razafimahefa N., Stussi J.M., Carron J.P. 1985. Composition chimique des biotites et typologie magmatique des granitoides. C.R Acad. Sc. Paris, 301:813-818.

Nekvasil H. 1988. Calculation of equilibrium crystallization paths of compositionally simple hydrous felsic melts. Am. Miner, 73:956-965.

Philipp R.P., Wild F., Duarte L.C., Oliveira A.S., Arend S.T., Rivera C.B., Samberg E., Morales L.F., Mallmann G. 2001. Caracterização litológica, estrutural e condições metamórficas do Complexo Camboriú, Itapema, SC. In: SBG, Simp. Nac. Est. Tect., 8, Extended Abstracts, p. 103-105.

Philipp R.P., Mallmann G., Bitencourt M.F., Souza E.R., Souza M.M.A, Liz J.D., Wild F., Arend S.T., Oliveira A.S., Duarte L., Rivera C.B. Prado M. 2003. A porção leste do Complexo Metamórfico Brusque. SC: caracterização litológica e evolução metamórfica. Rev. Bra. Geoc: 34: $12-34$

Pryer L.L. \& RobinY-P. 1996. Differential stress control on the growth and orientation of flame perthite: a paelostress-direction indicator. $J$. Struct. Geol., 18:1151-1166.

Roscoe R. 1952. The viscosity of suspension of rigid spheres. British J. Appl. Phys., 3:267-269.

Schmidt M.W. 1992. Amphibole composition in tonalite as a function of pressure: an experimental calibration of the Al-in-hornblende barometer. Contrib. Mineral. Petrol., 110:304-310.

Silva L.C. 1991. O Cinturão Metavulcanossedimentar Brusque e a evolução policíclica das faixas dobradas proterozóicas no sul do Brasil: uma revisão. Rev. Bras.Geoc, 21:60-73.

Silva L.C. 1999. Geocronologia U-Pb SHRIMP e Sm-Nd na Província Mantiqueira Meridional, no Cinturão Saldania (África do Sul) e a evolução do Ciclo Brasiliano/Pan-africano. Tese de Doutoramento, Instituto de Geociências, Universidade Federal do Rio Grande do Sul, 243p.

Silva L.C., Hartmann L.A., McNaughton N.J., Fletcher I.R. 2000. Zircon U/Pb SHRIMP dating of a Neoproterozoic overprint in Paleoproterozoic granitic-gneissic terranes, southern Brazil. Am. Miner., 85:649-667

Spear J.A. 1980. $\mathrm{NaSi}=\mathrm{CaAl}$ exchange equilibrium between plagioclase and amphibole: an empirical model. Cont. Mineral. Petrol.,72:33-41.

UFRGS 2000. Mapeamento geológico 1:25 000 de parte das Folhas Camboriú (MI2894/2) e Itajaí (2882/4), SC. Trabalho de Graduação do Curso de Geologia. Instituto de Geociências, Universidade Federal do Rio Grande do Sul. 7 vol.

Vyhnal C.R., McSween Jr. H.Y., Speer J.A. 1991. Hornblende chemistry in southern Appalachian granitoids: Implications for aluminium hornblende thermobarometry and magmatic epidote stability. Am. Miner:,76:176-188.

Watson E.B. \& Harrison T.M. 1983. Zircon saturation revisited: temperature and composition effects in a variety of crustal magma types. Earth Planet. Sci. Lett., 64:295-30.

Manuscrito A-1421

Recebido em 15 de março de 2003

Revisão dos autores em 20 de abril de 2004 Revisão aceita em 15 de maio de 2004 